\title{
A Comparative Study on Serum Magnesium in Pre-eclampsia and Non Pregnant Women
}

\author{
Heera Lal Roy ${ }^{* 1}$, Susmita Nargis ${ }^{2}$, Farhana Ferdaus ${ }^{3}$
}

\begin{abstract}
Introduction: There are many Hypertensive disorders in pregnancy like preeclampsia, eclampsia etc. Pre-eclampsia is the most common medical complication of pregnancy associated with increased maternal and infant mortality and morbidity. Some studies have implicated that low serum calcium levels may have a role in pre-eclampsia but other studies failed to find relation between low levels of these trace elements and pre-eclampsia. Materials and Methods: This cross sectional study was carried out in the Department of Biochemistry, Sylhet MAG Osmani Medical College in collaboration with the Department of Obstetrics and Gynaecology, Sylhet MAG Osmani Medical College Hospital during the period from January 2016 to December 2016. This Study was occured in among 31 pre-eclampsia patients, aged 20 to 40 years, and gestational age ranges from 20 to 40 weeks and 31 age matched normotensive non-pregnant women having no proteinuria. Serum magnesium was measured by Colorimetric method. Results: The mean serum magnesium level was $3.24( \pm 1.42) \mathrm{mg} / \mathrm{dl}$ in pre-eclampsia and was $3.30( \pm 1.5) \mathrm{mg} / \mathrm{dl}$ in normal women. The mean serum magnesium level did not differ significantly between the subjects of pre-eclampsia and normal women $(t=0 ; p<.05)$. Conclusion: The means of both data sets are equal. So we can conclude that there is no significant difference between them.
\end{abstract}

Keywords: Pre-eclampsia, Magnesium.

Number of Tables: 03; Number of References: 23; Number of Correspondence: 03.

*1. Corresponding Author:

\section{Dr. Heera Lal Roy}

Assistant Professor

Department of Biochemistry

Khulna City Medical College, Khulna.

Mobile: 01711986535

Email: roy036.hr@gmail.com

\section{Dr. Susmita Nargis}

Associate Professor

Department of Biochemistry

Ad-din Sakina Womens' Medical College, Jashore.

3. Dr. Farhana Ferdaus

Assistant Professor

Department of Community Medicine

Khulna City Medical College, Khulna.

\section{Introduction:}

Preeclampsia is one of the commonest causes of maternal mortality and morbidity ${ }^{1}$. The incidence of preeclampsia in developing countries is estimated to be $4-18 \%{ }^{2}$. Thus, $16 \%$ of all maternal death in developed countries and $9 \%$ of maternal deaths in Asia and Africa are said to be due to hypertensive disorders in pregnancy ${ }^{3,4}$. A worldwide perinatal and neonatal mortality rate of $10 \%$ is associated with preeclampsia ${ }^{5}$. Current evidence suggests that the endothelial dysfunction seen in preeclampsia may persist years after the episode, and therefore preeclamptic women may be at high risk of cardiovascular diseases later in life ${ }^{6}$.

Though the etiology of preeclampsia remains unclear, many theories suggest abnormal placental implantation and abnormal trophoblastic invasion as possible causes ${ }^{7}$. The molecular basis of this condition is unresolved in study ${ }^{8}$. It has been postulated that fluctuations in maternal serum ions may be the precipitating cause of elevated blood pressures in preeclampsia9,10. Dietary deficiency of mineral ions has been shown to have a harmful effect on the pregnant mother and growing fetus and possibly complicate preeclampsia ${ }^{11}$. Dietary deficiency of magnesium has been established to play a role in blood pressure regulation and hence development of preeclampsia $^{12}$. Evidence supporting routine magnesium supplementation for all pregnant women has not been substantiated by research, though most studies have reported reduced magnesium levels in pregnancy and worse levels in preeclampsia ${ }^{13}$. However, other studies have also reported a nonsignificant change in the serum magnesium levels of preeclamptic women compared to normal women $^{14}$

\section{Materials and Methods:}

This cross-sectional study was carried out in the Department of Biochemistry, Sylhet MAG Osmani Medical College in collaboration with the Department of Obstetrics and Gynaecology, Sylhet MAG Osmani Medical College Hospital during the period from January 2016 to December 2016. 31 pre-eclamptic patients, aged 20 to 40 years, and gestational age ranges from 20 to 40 weeks and 31 age matched normotensive non pregnant women having no proteinuria were included in group-A and Group-B respectively. Pregnant subjects were Primi \& having essential hypertension, systemic or endocrine disorders, malabsorption syndrome, and patients on magnesium supplementation were excluded. Detailed history about present pregnancy regarding pre-eclampsia and exclusion criteria were asked. Data were collected from the selected subjects on variables of interest using a semi-structured questionnaire by interview, observation, clinical examination, investigation and from the history. Blood pressure was measured in supine position or sitting position. Urine was tested for gross proteinuria (heat coagulation test). 
The pre-eclamptic patients were diagnosed by the presence of persistent hypertension (more than 140/90 $\mathrm{mm}$ of $\mathrm{Hg}$ ).

\section{Results:}

The mean age was $28.45( \pm 7.54)$ years in pre-eclampsia and $31.03( \pm 8.9)$ years in normotensive non-pregnant women; difference was not significant $(\mathrm{t}=0, \mathrm{p}<.05)$ (Table I), the means of both data sets are equal so we can conclude that there is no significant difference between them.

Table-I: Age of the respondents.

\begin{tabular}{c|c|c|c|c|c}
\hline $\begin{array}{c}\text { Age of } \\
\text { pre-eclampsia } \\
\text { women }\end{array}$ & Number & $\begin{array}{c}\text { Percentage } \\
\%\end{array}$ & $\begin{array}{c}\text { Age of } \\
\text { pre-eclampsia } \\
\text { women }\end{array}$ & Number & $\begin{array}{c}\text { Percentage } \\
\%\end{array}$ \\
\hline $20-24$ & 14 & 45.16 & $20-24$ & 13 & 41.93 \\
\hline $25-29$ & 6 & 19.35 & $25-29$ & 3 & 9.67 \\
\hline $30-34$ & 4 & 12.90 & $30-34$ & 2 & 6.45 \\
\hline $35-39$ & 2 & 6.45 & $35-39$ & 3 & 9.67 \\
\hline$\geq 40$ & 5 & 16.12 & $\geq 40$ & 10 & 32.25 \\
\hline Total & 31 & 100 & Total & 31 & 100 \\
\hline $\begin{array}{l}\text { Mean age } \\
28.45( \pm 7.54)\end{array}$ & & & $\begin{array}{c}\text { Mean age } \\
\text { (1.03 } \pm 8.9)\end{array}$ & & \\
\hline
\end{tabular}

The mean serum magnesium level was $3.24( \pm 1.42) \mathrm{mg} / \mathrm{dl}$ in pre-eclampsia and was $3.30( \pm 1.5) \mathrm{mg} / \mathrm{dl}$ in normal women. The mean serum magnesium level did not differ significantly between the subjects of pre-eclampsia and non pregnant women $(\mathrm{t}=0 ; \mathrm{p}<.05)$ (Table- II). The means of both data sets are equal so we can conclude that there is no significant difference between them.

Table-II: Serum Mg+ level of the respondents.

\begin{tabular}{c|c|c|c|c|c}
\hline $\begin{array}{c}\text { Serum Mg+ of } \\
\text { pre-eclampsia } \\
\text { women mg/dl }\end{array}$ & Number & $\begin{array}{c}\text { Percentage } \\
\%\end{array}$ & $\begin{array}{c}\text { Serum Mg+ of } \\
\text { Non-pregnant } \\
\text { women mg/dl }\end{array}$ & Number & $\begin{array}{c}\text { Percentage } \\
\%\end{array}$ \\
\hline $1-2.9$ & 15 & 48.38 & $1-2.9$ & 15 & 48.38 \\
\hline $3-4.9$ & 12 & 38.70 & $3-4.9$ & 11 & 35.48 \\
\hline $5-6.9$ & 4 & 12.90 & $5-6.9$ & 5 & 16.12 \\
\hline $7-8.9$ & 0 & 0 & $7-8.9$ & 0 & 0 \\
\hline$\geq 9$ & 0 & 0 & $\geq 9$ & 0 & 0 \\
\hline Total & 31 & 100 & Total & 31 & 100 \\
\hline Mean & & & Mean & & \\
$3.24( \pm 1.42)$ & & & $3.30( \pm 1.5)$ & & \\
\hline
\end{tabular}

The mean body mass index was $26.45( \pm 2.17) \mathrm{Kg} / \mathrm{M}^{2}$ in pre-eclampsia and $19.26( \pm 7.9) \mathrm{mg} / \mathrm{M}^{2}$ in normotensive non-pregnant women. The mean body mass index in pre-eclampsia was significantly higher compared to normotensive non-pregnant women $(\mathrm{t}=6.601 ; \mathrm{p}<0.001)$ (Table- III).

Table-III: BMI of the respondents.

\begin{tabular}{|c|c|c|c|c|c|}
\hline $\begin{array}{c}\text { BMI of } \\
\text { pre-eclampsia } \\
\text { women } \mathrm{Kg} / \mathrm{M}^{2}\end{array}$ & Number & $\begin{array}{c}\text { Percentage } \\
\%\end{array}$ & $\begin{array}{c}\text { BMI } \\
\text { Non-pregnant } \\
\text { women } \mathrm{Kg} / \mathrm{M}^{2}\end{array}$ & Number & $\begin{array}{c}\text { Percentage } \\
\%\end{array}$ \\
\hline$>18$ & 0 & & $>18$ & 4 & \\
\hline $18-20$ & 0 & & $18-20$ & 7 & \\
\hline $21-23$ & 4 & & $21-23$ & 14 & \\
\hline $24-26$ & 8 & & $24-26$ & 4 & \\
\hline $27-29$ & 19 & & $27-29$ & 2 & \\
\hline Total & 31 & 100 & Total & 31 & 100 \\
\hline $\begin{array}{l}\text { Mean } \\
26.45( \pm 2.17)\end{array}$ & & & $\begin{array}{l}\text { Mean } \\
19.26( \pm 7.9)\end{array}$ & & \\
\hline
\end{tabular}

\section{Discussion:}

Serum concentrations of various macrominerals are altered during pregnancy with changes in the mother's physiology and the requirements of growing fetus. Changes on serum level of Magnesium ( $\mathrm{Mg}$ ) during pregnancy were estimated. In addition, it has been reported that reduction in serum level of $\mathrm{Mg}$ during pregnancy might be possible contributors in etiology of pre-eclampsia (PE), and supplementation of these minerals to diet may be of value to prevent $\mathrm{PE}^{15}$. The mean age was $28.45( \pm 7.54)$ years in pre-eclampsia and $31.03( \pm 8.9)$ years in normotensive non-pregnant women (Table I), the means of both data sets are equal so we can conclude that there is no significant difference between them.This result was consistent with the study of Golmohammad lou et al. ${ }^{16}$ that the mean age of the pre-eclampsia women was $25.70 \pm 1.20$ years. Akhtar et al. ${ }^{17}$ that the mean age of the pre-eclampsia mother was $25.20 \pm 4.85$ years also supported this result.

In the current study, the mean serum magnesium level was $3.24( \pm 1.42) \mathrm{mg} / \mathrm{dl}$ in pre-eclampsia and was 3.30 $( \pm 1.5) \mathrm{mg} / \mathrm{dl}$ in normal women. The mean serum magnesium level did not differ significantly between the subjects of pre-eclampsia and normal women $(\mathrm{t}=0$; $\mathrm{p}<.05)$. This result was supported by different studies ${ }^{18,19,20}$ that there was no significant difference between the plasma magnesium of the patients and controls. But several other studies ${ }^{21,22}$ showed that there was significantly lower serum magnesium in pre-eclampsia than that of normal pregnancy.

The mean body mass index was $26.45( \pm 2.17) \mathrm{Kg} / \mathrm{M}^{2}$ in pre-eclampsia and $19.26( \pm 7.9) \mathrm{mg} / \mathrm{M}^{2}$ in normotensive non-pregnant women. The mean body mass index in pre-eclampsia was significantly higher compared to normotensive non-pregnant women $(\mathrm{t}=6.601 ; \mathrm{p}<0.001)$. Several other studies did not show significant difference of body mass index between the two groups $(p>0.05)^{14}$. But Akhtar et al. ${ }^{23}$ found that the mean body mass index of the subjects with pre-eclampsia was 25.30 (SEM 0.36) $\mathrm{Kg} / \mathrm{M}^{2}$ and normal women was 23.48 (SEM 0.28) Kg/M ${ }^{2}$. There was a significant difference of body mass index between the two groups $(\mathrm{p}<0.001)$.

\section{Conclusion:}

Serum Magnesium is very essential during pregnancy. This study showed that serum magnesium level did not differ significantly between pre-eclamptic and non pregnant women. It may be concluded that serum magnesium have no association in occurrence of pre-eclampsia. However further multicenter study involving large sample needed should be carried out to find the association between preeclampsia and serum calcium.

Conflict of Interest: None.

\section{Acknowledgement:}

The author thanks to Dr. Susmita Nargis, Associate Professor (Biochemistry), Ad-din Sakina Women's Medical College, for her assistance in statistical analysis. 


\section{References:}

1. Sukonpan K, Phupong V. Serum calcium and serum magnesium in normal and preeclamptic pregnancy. Arch Gynecol Obstet. 2005; 273(1): 12-16.

https://doi.org/10.1007/s00404-004-0672-4

PMid:15480721

2. Villar J, Betran A, Gulmezoglu M. Epidemiological basis for the planning of maternal health services. WHO/RHR. 2001; 111: 298-302.

3. Khan KS, Wojdyla D, Say L, Gülmezoglu AM, Van Look PF. WHO analysis of causes of maternal death: a systematic review. Lancet. 2006; 367(9516): 1066-1074.

https://doi.org/10.1016/S0140-6736(06)68397-9

4. Lassey A, Wilson J. Trends in maternal mortality in Korle Bu Hospital. Ghana Med J. 1998; 32a: 910-916.

5. Maynard SE, Karumanchi SA. Angiogenic factors and preeclampsia. Paper presented at: Seminars in Nephrology; 2011.

https://doi.org/10.1016/j.semnephrol.2010.10.004

PMid:21266263 PMCid:PMC3063446

6. Mutter WP, Karumanchi SA. Molecular mechanisms of preeclampsia. Microvasc Res. 2008; 75(1): 1-8.

https://doi.org/10.1016/j.mvr.2007.04.009

PMid:17553534 PMCid:PMC2241748

7. Smith RA, Kenny LC. Current thoughts on the pathogenesis of pre-eclampsia. Obstet Gynaecol. 2006; 8(1): 7-13.

https://doi.org/10.1576/toag.8.1.007.27202

8. Roberts J, Cooper D. Pathogenesis and genetics of pre-eclampsia. Lancet. 2001; 357(9249): 53-56.

https://doi.org/10.1016/S0140-6736(00)03577-7

9. Hanisch CG, Pfeiffer KA, Schlebusch H, Schmolling J. Adhesion molecules, activin and inhibin - candidates for the biochemical prediction of hypertensive diseases in pregnancy? Arch Gynecol Obstet. 2004; 270(2): 110-115.

https://doi.org/10.1007/s00404-003-0514-9

PMid:12898146

10. Bussen S, Sütterlin M, Steck T. Plasma endothelin and big endothelin levels in women with severe preeclampsia or HELLP-syndrome. Arch Gynecol Obstet. 1999; 262(3-4): 113-119.

https://doi.org/10.1007/s004040050238

PMid:10326629

11. Raman L, Shatrugna V. Nutrition during pregnancy and lactation. In: Mahtab SB, Prahlad RN, Vinodini R, editors. Textbook of Human Nutrition. New Delhi: IBH; 2002:509.

12. Sarma P, Gambhir S. Therapeutic uses of magnesium. Indian J Pharmacol. 2005; 27: 7-13.
13. Roberts JM, Myatt L, Spong CY. Eunice Kennedy Shriver National Institute of Child Health and Human Development Maternal-Fetal Medicine Units Network. Vitamins $\mathrm{C}$ and $\mathrm{E}$ to prevent complications of pregnancy-associated hypertension. N Engl J Med. 2010; 362(14): 1282-1291.

https://doi.org/10.1056/NEJMoa0908056

PMid:20375405 PMCid:PMC3039216

14. Golmohammad LS, Amirabi A, Yazdian M, Pashapour N. Evaluation of serum calcium, magnesium, copper and zinc levels in women with pre-eclampsia. Iran J Med Sci. 2008; 33(4): 231-234.

15. Dickinson HO, Nicolson DJ, Campbell F, Cook JV, Beyer FR, Ford GA, et al. Magnesium supplementation for the management of essential hypertension in adults. Cochrane Database Syst Rev. 2006; 19: CD004640.

https://doi.org/10.1002/14651858.CD004640.pub2

16. Golmohammad Lou S, Amirabi A, Yazdian M, Pashapour N. Evaluation of Serum Calcium, Magnesium, Copper and Zinc Levels in Women with Pre-eclampsia. Iran JMedSci. 2008; 33: 231-4.

17. Akhtar S, Begum S, Ferdousi S. Calcium and Zinc Deficiency in Pre-eclamptic Women. J Bangladesh Soc Physiol. 2011.

18. Kanagal DV, Rajesh A, Rao K, Devi UH, Shetty H, Kumari S, et al. Levels of Serum Calcium and Magnesium in Pre-eclamptic and Normal Pregnancy: A Study from Coastal. India. J Clin Diagn Res. 2014; 8: OC01-4.

https://doi.org/10.7860/JCDR/2014/8872.4537

PMid:25177604 PMCid:PMC4149110

19. Punthumapol C, Kittichotpanich B. Serum calcium, magnesium and uric acid in pre-eclampsia and normal pregnancy. J Med Assoc Thai. 2008; 91: 968-73.

20. Adewolu OF. Serum sodium, potassium, calcium and magnesium in women with pregnancy-induced hypertension and preeclampsia in Oredo local government, Benin Metropolis: A pilot study. Afr J Med Health Sci. 2013; 12: 1-5.

https://doi.org/10.4103/2384-5589.129914

21. Akinloye O, Oyewale OJ, Oguntibeju OO. Evaluation of trace elements in pregnant women with pre-eclampsia. Afr J Biotechnol. 2010; 9: 5196-202.

22. Lambe S, Mahajan B, Muddeshwar M. Comparative Study of Serum Calcium, Magnesium and Zinc Levels in Pre-eclampsia and Normal Pregnancy. International Journal of Recent Trends in Science and Technology. 2014; 9: 422-6.

23. Akhtar S, Begum S, Ferdousi S. Calcium and Zinc Deficiency in Pre-eclamptic Women. J Bangladesh Soc Physiol. 2011. 